Article

\title{
A Modern Approach to Disinfection, as Old as the Evolution of Vertebrates
}

\section{Franco Migliarina ${ }^{1}$ and Sergio Ferro ${ }^{2, *}$}

1 Administrative Services Business, ASL AT, via Conte Verde 125, 14100 Asti, Italy;

E-Mail: fmigliarina@asl.at.it

2 Department of Chemical and Pharmaceutical Sciences, University of Ferrara, via Fossato di Mortara, 17-27, 44121 Ferrara, Italy

* Author to whom correspondence should be addressed; E-Mail: fre@unife.it; Tel.: +39-0532-455166; Fax: +39-0532-240709.

External Editor: Manu Malbrain

Received: 6 October 2014; in revised form: 17 November 2014 / Accepted: 8 December 2014 / Published: 19 December 2014

\begin{abstract}
The immune system of vertebrates "naturally" produces hypochlorous acid ( $\mathrm{HOCl})$ to fight against bacteria and pathogens. A patented electrochemical technology mirrors the above defense system, allowing the synthesis of $\mathrm{HOCl}$ solutions through the electrolysis of water enriched in salts, at the level of a few grams per liter. The system allows for the careful control of the $\mathrm{pH}$ of produced solutions, with consequent optimization of their activity. Once the $\mathrm{HOCl}$ is introduced into the water system; it is able to remove the biofilm from pipe network; significantly decreasing the level of Legionella colonization; within 8-10 weeks from the beginning of the disinfection approach. The technology has been applied in a variety of healthcare facilities, both in Italy and in neighboring European countries. In the present paper, two successful case studies are briefly presented: Data were obtained from experiences in two different healthcare facilities, one in Italy and the other in Germany. Destruction of biofilm was indirectly testified by an increase of total organic carbon content of water; as a consequence, and because of the dosing of the disinfecting agent, some $\mu \mathrm{g} / \mathrm{L}$ of total halomethanes were also formed. However, both compositional features were only observed during the initial stages of the disinfection treatment.
\end{abstract}


Keywords: hypochlorous acid; water disinfection; Legionella; electrochemical synthesis; anolyte

\section{Introduction}

Different approaches are currently being used to fight against opportunistic pathogens present in aquatic environments, such as Legionella. Since each method has some pros and, unfortunately, some cons, a universally applicable solution has not been identified yet. The approach described in this study was inspired by observing how the immune system of vertebrates works to defend the body from any form of chemical, traumatic or infectious insult to its integrity (see e.g., [1]). Nonspecific immunity is substantially based on the activity of neutrophils and macrophages leukocytes, which have the fundamental task to capture and destroy foreign substances, through phagocytosis. Of great importance is the action of myeloperoxidase (MPO), an enzyme that produces hypochlorous acid ( $\mathrm{HOCl}$ ) from hydrogen peroxide $\left(\mathrm{H}_{2} \mathrm{O}_{2}\right)$ and chloride anion $\left(\mathrm{Cl}^{-}\right)$, during the neutrophils' respiratory burst [2-4].

Hypochlorous acid possesses a particularly effective cytotoxic activity [5-7]. Unfortunately, in contrast to other forms of so-called active chlorine (i.e., hypochlorite and gaseous chlorine), the HOCl molecule is rather unstable, and cannot be stored for long periods and used at request. To produce it, three different methods can be utilized [4]: Hydrolysis of chlorine, electrolysis of chloride-containing solutions, and acidification of hypochlorite. The first and third of the methods have drawbacks and dangers, mainly related with the use or the possible release of gaseous chlorine. As a result, the easiest and safest synthetic path is electrochemical production, through electrolysis of a brine solution. Various approaches exist, which are all based on electrochemical cells, provided with or without a separator to avoid reaction or decomposition of products synthesized at the anodes upon contact with the cathodes. Only a few of them allow the synthesis of a biocide solution under well-controlled and reproducible conditions, and the number of useful devices is further reduced when the constraint of a product with a neutral $\mathrm{pH}$ is introduced. The latter is important, as it is linked with the reactivity of the active ingredient [8-11] and of related chemical equilibria (i.e., conversion of the active chlorine to chlorite and chlorate). In addition, a neutral $\mathrm{pH}$ is safer for both the user and the target applications (e.g., minimization of corrosion problems).

The Ecas4 Approach. To meet with the above requirements, an Italian company (Ecas srl) has recently patented a technology that relies upon a reactor with four chambers [12], as sketched in Figure 1. As described in the patent application, the incoming solution (having a flow rate comprised between 40 and $160 \mathrm{~L} / \mathrm{h}$, depending on reactor size) is distributed between two cathode compartments, and is thus subjected to a single cathodic treatment (cathodes made of titanium are used [13]). Subsequently, the solution is passed through two anodic treatments in series (typically, the anodes are titanium supports covered with an Iridium-based mixed oxide coating; ruthenium is accurately avoided, being for example not allowed by Italian legislation [13]).

By feeding the electrochemical reactor with $24 \mathrm{~V} \mathrm{DC}$, and operating with a dilute brine solution that contains $0.4 \%-0.5 \%$ of $\mathrm{NaCl}$, about $50 \mathrm{~A}$ of current are obtained (electrode current density around $250 \mathrm{~A} / \mathrm{m}^{2}$ ), which allow the synthesis of $350-400 \mathrm{mg} / \mathrm{L}$ of active chlorine. With reference to the anodic 
treatments, based on a flow rate of $100 \mathrm{~L} / \mathrm{h}$ and considering that about $10 \%$ of the incoming flow is discarded to control the $\mathrm{pH}$, residence times close to $0.35 \mathrm{~s}$ can be estimated.

Figure 1. Schematic representation of the electrochemical reactor with four chambers.

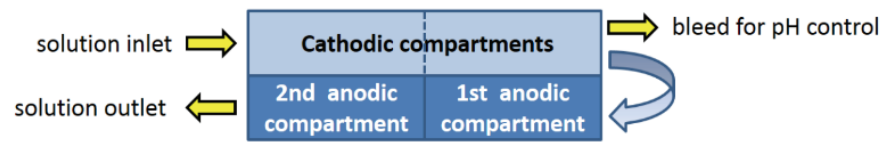

The Ecas approach may be considered as an optimization of the technology for electrochemical activation of water proposed by the Russian school [14,15], allowing the production of the so-called anolyte: A solution containing hypochlorous acid. A given $\mathrm{pH}$ is rigorously maintained at the desired value by the apparatus through the controlled discharge of part of the catholyte. The suitable bleeding of the latter is accomplished by means of an electric valve, whose functioning is driven by a $\mathrm{pH}$ sensor placed on the anolyte output. A conductivity sensor controls the salt content in the diluted brine, and another device measures the oxidation-reduction potential of the anolyte. When a parameter is outside the designated range, the synthesized product is discarded, while automatic regulators try to correct the anomaly. As a result, an anolyte with constant and reproducible characteristics is synthesized, irrespectively from variations in water pressure or other inconveniences (e.g., wear of the catalytic electrode coating).

The benefits deriving from the use of hypochlorous acid (active chlorine at $\mathrm{pH} \leq 7.5$ ), compared to those of using hypochlorite (active chlorine at $\mathrm{pH}>7.5$ ) can be summarized as follows:

1. Higher disinfectant efficacy of $\mathrm{HOCl}$, with respect to $\mathrm{ClO}^{-}$(about two orders of magnitude, as demonstrated also experimentally; see e.g., [16]); accordingly, the use of $\mathrm{HOCl}$ makes it possible to obtain results comparable to those attainable with the use of hypochlorite, but using lower concentrations.

2. $\mathrm{HOCl}$ apparently behaves like a source of hydroxyl radicals, rather than as a chlorine-containing oxidizing agent, thus minimizing the risk of formation of undesired byproducts [17].

3. A neutral solution does not alter the $\mathrm{pH}$ characteristics of the treated liquid (often a potable water), and provides greater assurance concerning possible problems of corrosion for metal piping.

With a second patent application [18], the technology has been further improved, borrowing the zero-gap principle, i.e., with electrode in direct contact with the separating membrane, from the fuel cell and chlor-alkali industries (see e.g., [19]). This allows to reduce the salinity of the diluted brine (with benefits in terms of stability of the anolyte and minimization of non-active chemicals), while reducing the possible heating due to ohmic drop (in general, heat is deleterious, both from a chemical point of view as for the stability of the electrodes and of the membrane).

Considering Italy and a few neighboring European countries (Spain, Germany, Slovenia), the effectiveness of the above-discussed anolyte, for the control and possible eradication of Legionella in healthcare facilities, has been extensively verified. In most cases, the same healthcare facilities have carried out comparative tests, in order to attest the effectiveness of the anolyte-based disinfecting system, in comparison to other approaches (systems based on monochloramines, hydrogen peroxide and silver, chlorine dioxide, UV disinfection, thermal shocks). Unfortunately, healthcare facilities are usually not 
prone to share all obtained results, as this would mean admitting problems of contamination within the water network of the structure. Thus, independent tests have been also carried out by different university groups (in Italy, Germany and Slovenia) in order to investigate on the various aspects of the application. In relation to the applicability to water supply systems, attention has been specifically addressed to rule out possible problems due to corrosiveness of the anolyte, and to the verification of its biocide effectiveness against major pathogens (i.e., Pseudomonas aeruginosa, Staphylococcus aureus, Escherichia coli, Aspergillus niger, Candida albicans). Referring also to the work by other groups, the list of pathogens against which anolytes have been tested so far is impressive, as underlined in a recent review by Reynolds and coworkers [20].

The present study aims at reporting and briefly discussing some of the data obtained from experiences in two healthcare facilities, one in Italy and the other in Germany.

\section{Methods}

The investigations were carried out at the University Hospital of Dresden (Germany) and at the Cardinal Massaia Hospital, Asti (Italy).

University Hospital of Dresden, Dresden, Germany. Due to the positioning of the buildings in a pavilion system, the Dresden University Hospital has used several different hot water systems decontamination methods. Besides the electrolytic process presently under discussion, thermal disinfection, a combination of UV with ultrasound or the filtration of drinking water at the point of use have all been used. Despite several thermal decontaminations, colony counts of Legionella pneumophila in the hot water system of the department of neurology were repeatedly over 10,000 colony-forming units (CFU)/L. Isolates were determined to belong to several serogroups, including serogroup 1 that is associated with a higher virulence. A two-story building of 15 years with 45 beds was selected to assess the performance of the Ecas technology.

Cardinal Massaia Hospital, Asti, Italy. The Asti hospital is organized in six departments, for a total of 471 beds for inpatient admissions and 51 places for day-hospital. In addition, a surgical unit with 11 rooms, a block of Day Surgery and an obstetric room are located on the -1 , 2nd and 3rd floor, respectively. The total area of the Asti hospital amounts to $125,000 \mathrm{~m}^{2}$; the daily average attendance is about 450 patients, and the employment index is equal to $90 \%$. Nosocomial infections are prevented by using control measures against Legionella proliferation in the hot water distribution system. The plant is divided into several sub-stations: Each one consists of a heat exchanger, fed by water at $90{ }^{\circ} \mathrm{C}$ coming from the main heating plant, 11 vertical tanks and 1 horizontal tank in galvanized steel, internally coated with Teflon. The distribution plant consists of a recirculation loop, in order to keep an optimal temperature in the vicinity of the different peripheral points. The cold water pertaining to the hot water system network is softened at $4^{\circ} \mathrm{f}$. In general, a complete elimination of bacteria is difficult to achieve with any disinfection approach. In this study, the efficacy of two continuous dosing methods for the eradication of Legionella from hospital water supplies has been evaluated and compared. Both approaches require the continuous dosing of a biocide into the hot water system: Method 1 involves the use of an electrochemically activated water (the Ecas anolyte), containing hypochlorous acid at neutral $\mathrm{pH}$, while method 2 relies upon a solution of hydrogen peroxide and silver (Cillit Allsil Super $25 \mathrm{Ag}$ ). It is worth mentioning that the latter approach is not always applicable, being for example not permitted 
by German legislation for continuous treatment of drinking water [21]. The two continuous disinfection systems were installed in the Asti hospital in two distinct water supplies.

In both cases (Dresden and Asti hospitals), the composition of the just-prepared anolyte was as follows: Hypochlorous acid $325 \mathrm{mg} / \mathrm{L}$; pH $7.0 \pm 0.1$; oxidation-reduction potential (ORP) 850-900 mV; chloride content less than $0.5 \%$.

\subsection{Sample Collection}

Between November 2009 and October 2010, hot water samples were collected from different points of use (showers, sinks) within building 62, Dept. of Neurology, at the Dresden Hospital; the apparatus for the anolyte synthesis was installed and started operating on August 11, 2010.

Concerning the Cardinal Massaia Hospital (where the investigation was launched in late 2008), two samplings from seven different points, within each water system, were performed before the installation of the disinfection plants, and then repeated after three weeks from the installation of the disinfection systems. Subsequently, eight samplings were periodically performed for 5 months (every 2 weeks, during the first 3 months, and once a month for the subsequent 2 months). In total, 70 samples were analyzed for each system.

In all cases, water sampling was performed by means of large containers ( $>5$ liters, collected by leaving an air space in the bottle), adding an excess of sodium thiosulfate ( $\sim 100 \mathrm{mg}$, used as inactivating agent) to specimens that contain a residual biocide content. Samples were collected both before and after flushing operations (since stagnant water favors Legionella growth, different results are expected).

Cultures were performed following standard quantitative protocols (detection limit: $20 \mathrm{CFU} / \mathrm{L}$ ) [22,23]. Samples ( 5 liters each) were concentrated by filtration on a $0.2 \mu \mathrm{m}$ pore-diameter polycarbonate membrane (Millipore, Ireland); then, the suspensions were re-suspended in $5 \mathrm{~mL}$ of water and shaken vigorously. Heat treatment for selective inhibition of non-Legionella bacteria were performed as described in [23]. Centrifuged and re-suspended suspensions $(1 \mathrm{~mL})$ were sub-cultured on BCYE, BMPA and MWY agar [24] (three replicates, dispensing $0.1 \mathrm{~mL}$ each), incubated at $37 \pm 1{ }^{\circ} \mathrm{C}$ for 15 days, to allow Legionella colonies counting and typing. Results were reported as total counts of Legionella.

The residual biocide content in water samples was quantified during sampling by means of the standard N,N-diethyl-1,4-phenylenediamine colorimetric method [25]. Redox and pH were measured by means of a multiparametric probe.

\subsection{Biocide Dosing}

Once produced, the anolyte is injected in the water network of the structure by means of a diaphragm pump, which must be sized depending on the amount of water to be treated. The concentration of the active ingredient in the anolyte was always between 300 and $400 \mathrm{mg} / \mathrm{L}$ (rather low when compared to other forms of chlorine-based disinfectants). The pump is capable of injecting up to a distance of 120 meters and can operate in volumetric or proportional mode. On-line measurement of anolyte concentration takes place by means of a potentiostatic probe, which sends the result to a residual chlorine analyzer, connected to the injecting pump. Two different probes are typically used: One in relatively close proximity and the other located far from the injection point; in this way, the biocide can be suitably dosed, without exceeding the maximum residual disinfectant limits set by the legislation in force. 


\section{Results and Discussion}

\subsection{Decontamination of Hot Water System - Dresden University Hospital (Germany)}

At the beginning of the monitoring program (see Table 1), analyses showed a systemic colonization of the hot water network of the department of Neurology: Colony counts of Legionella pneumophila were repeatedly over 10,000 CFU/L. Within a week from the installation of the HOCl generating unit, a significant reduction in colony counts of L. pneumophila at water outlets was achieved. Colony counts increased slightly afterwards, plausibly because of the destruction of biofilm. However, the contamination completely disappeared after about 8 weeks. No Legionella was detected 6 months later during the manufacturer's recommended inspection. Technical problems such as corrosion or leaching of the piping were not reported. During the first 8 weeks, chemical analyses have determined that the chlorine content in tap water did not exceed $0.6 \mathrm{mg} / \mathrm{L}$. Actually, the German regulation allows a chlorine content in drinking water up to $1.2 \mathrm{mg} / \mathrm{L}$ at the injection point, and between 0.1 and $0.3 \mathrm{mg} / \mathrm{L}$ at the points of use; exceptionally, the chlorine concentration can be raised up to $0.6 \mathrm{mg} / \mathrm{L}[21,26]$. Patients and staff tolerated the temporary slightly higher chlorine smell.

Table 1. Selection of data on Legionella detection (values expressed in colony-forming units $(\mathrm{CFU}) / \mathrm{L})$; Department of Neurology, Dresden University Hospital. Asterisks refer to withdrawals performed with the electrochemical technology implemented in the water system (the electrochemical technology was put into operation on 11.08).

\begin{tabular}{|c|c|c|c|c|c|c|c|c|c|}
\hline Sample & Notes & 02.11 & 15.11 & 01.12 & 09.02 & 15.06 & 02.08 & $* 16.08$ & $* 23.08$ \\
\hline shower in room & before flushing & 2000 & 1000 & & & 100,000 & 10,000 & 0 & 1,000 \\
\hline 124 & after flushing & 6000 & 2000 & & & 33,000 & 3000 & 0 & 0 \\
\hline Shower in room & before flushing & 1000 & 1000 & 2000 & 0 & 3000 & 0 & 0 & 0 \\
\hline 134 & after flushing & 8000 & 11,000 & 5000 & 7000 & 11,000 & 5000 & 0 & 4 \\
\hline \multirow{2}{*}{ Sink in room 134} & before flushing & & 12,000 & 1000 & 0 & 40 & 0 & 0 & 0 \\
\hline & after flushing & & 14,000 & 6000 & 15,000 & 3000 & 2000 & 0 & 1000 \\
\hline \multirow{2}{*}{ Sink in room 61} & before flushing & 1000 & & 10,000 & 3000 & 7000 & 1000 & 100 & 2,000 \\
\hline & after flushing & 16,000 & & 3000 & 6000 & 7000 & 2000 & 20 & 2,000 \\
\hline Sample & Notes & *30.08 & *06.09 & $* 13.09$ & *20.09 & $* 27.09$ & $* 11.10$ & $* 18.10$ & $* 25.10$ \\
\hline Shower in room & before flushing & 3000 & 0 & 20 & 0 & 1000 & 0 & 0 & 0 \\
\hline 124 & after flushing & 280 & 0 & 0 & 0 & 4000 & 0 & 0 & 0 \\
\hline Shower in room & before flushing & 1000 & 0 & 0 & 0 & 0 & 0 & 0 & 0 \\
\hline 134 & after flushing & 1000 & 0 & 0 & 0 & 1000 & 0 & 0 & 0 \\
\hline \multirow{2}{*}{ Sink in room 134} & before flushing & 4000 & 0 & 0 & 0 & 2000 & 0 & 0 & 0 \\
\hline & after flushing & 4000 & 0 & 0 & 0 & 1000 & 0 & 0 & 0 \\
\hline \multirow{2}{*}{ Sink in room 61} & before flushing & 28,000 & 14,000 & 70 & 0 & 2000 & 0 & 0 & 0 \\
\hline & after flushing & 15,000 & 1000 & 20 & 0 & 4000 & 0 & 0 & 0 \\
\hline
\end{tabular}

Obtained results (Table 1) demonstrate an immediate reduction and eventual eradication of microbial contamination by Legionella in the water system, after about two months of operation. 
3.2. Evaluation of Two Disinfection Systems for Legionella Eradication - Cardinal Massaia Hospital, Asti (Italy)

Pre-treatment samples from water supply 1 showed Legionella contamination of $60-180 \mathrm{CFU} / \mathrm{L}$ in the hot water tank, and of 300-16,000 CFU/L in distal points. After starting the anolyte-based disinfection system (method 1: Dosing of active chlorine was between 1.2 and $0.3 \mathrm{mg} / \mathrm{L}$, mean $0.6 \mathrm{mg} / \mathrm{L}$ ), all samples showed a clear reduction in colony counts $(\leq 100 \mathrm{CFU} / \mathrm{L})$. Samples from water supply 2 showed initial contaminations in the range 180-24,000 CFU/L. After starting the disinfection, by dosing $2 \mathrm{mg} / \mathrm{L}$ of hydrogen peroxide (method 2), the contamination reduced to 20-15,000 CFU/L. During the observation period, the product was dosed at variable concentrations and only in the second-last sampling, in the presence of the highest dose of biocide $(>25 \mathrm{mg} / \mathrm{L})$, the culture counts were negative. However, the contamination appeared again in the last sampling $\left(\mathrm{H}_{2} \mathrm{O}_{2}\right.$ at $\left.2 \mathrm{mg} / \mathrm{L}\right)$, with values up to $600 \mathrm{CFU} / \mathrm{L}$.

Method 1 proved to be effective in eradicating Legionella from the hospital water supply, with active chlorine concentration $>0.2 \mathrm{mg} / \mathrm{L}$ (the Italian legislation suggests a level of $0.2-0.3 \mathrm{mg} / \mathrm{L}$ at the point of use [27]). In contrast, method 2 was not efficient, at least at the biocide concentration proposed by the manufacturer. After the six-months research at one of the twelve hot-water circuits of the large Hospital of Asti, the medical management decided to install the anolyte-producing unit on all hot-water systems and units were installed in all buildings in October-November 2009. Results shown in Figure 2 refer to the first months of operation of the system (the chart legend reports the code of the rooms from where the samples were taken). From 2010 onwards, trends are actually straight lines connecting colony count data comprised between 50 and $100 \mathrm{CFU} / \mathrm{L}$. Occasional rises (never exceeding $300 \mathrm{CFU} / \mathrm{L}$ ) coincided with maintenance or extended periods of non-utilization [28].

Figure 2. Trend of Legionella colony counts, as a function of time, in the first months of operation of the anolyte-based disinfection system (method 1). Cardinal Massaia Hospital, Asti. From 2010 onwards, the contamination remained constantly below 100 CFU/L.
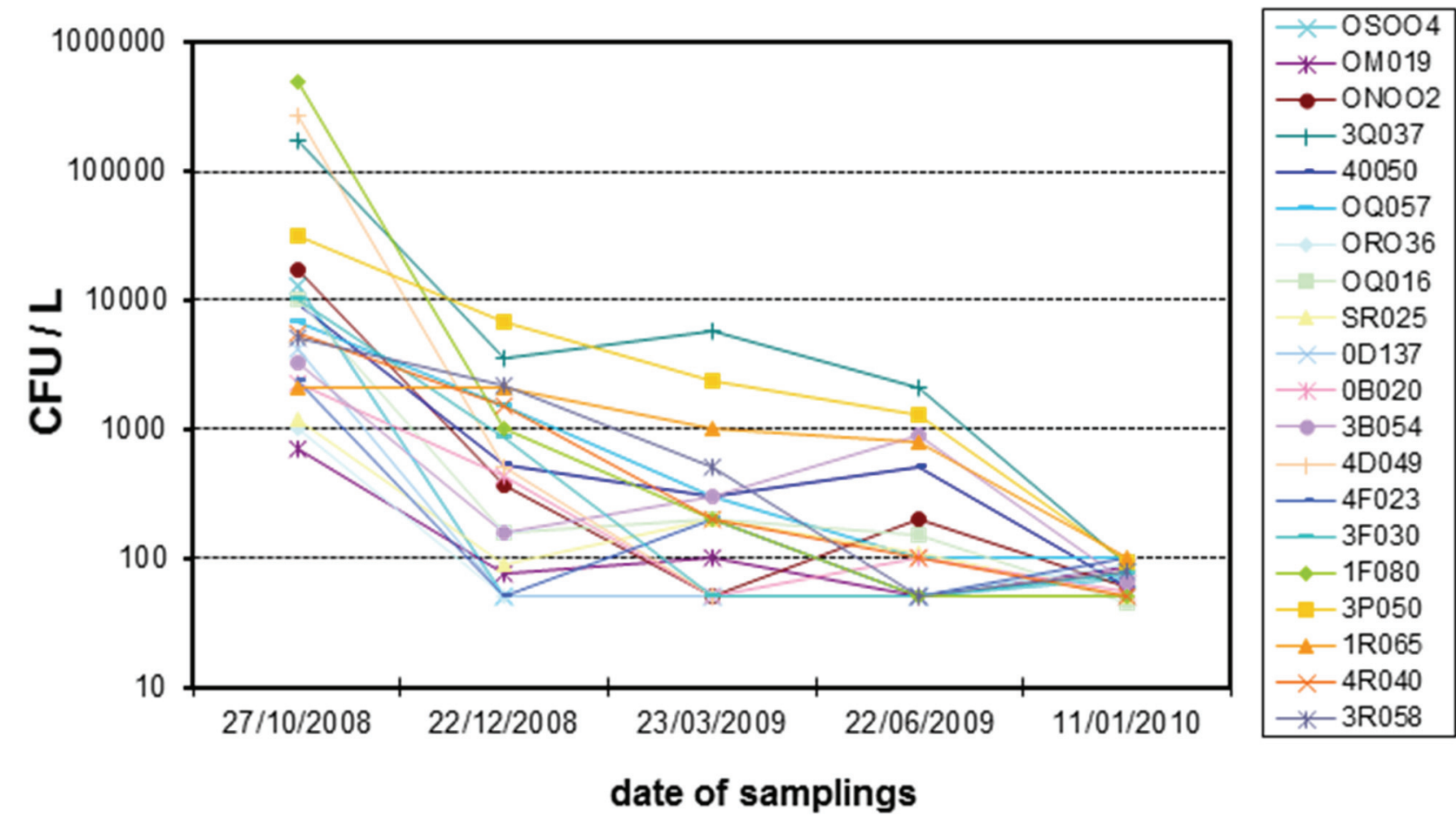
In all cases, the quality of water was investigated before and after the implementation of the anolyte-based system, by analyzing a number of common parameters [29,30]. In particular, the trend of total organic carbon (TOC) and the formation of halogenated byproducts (total halomethanes, THMs, and chloroform) can be reliably related to the functioning of the system, as shown in Table 2. Looking at the data, it is evident that the TOC initially increased, as a result of the implementation of the system in the water network, but subsequently decreased, thus suggesting that the biofilm was initially attacked and then destroyed. Since organic substances represent a suitable substrate for chlorination reactions (which are plausibly due to the hypochlorite fraction of the dosed biocide), some THMs are formed during biofilm destruction. Since their amount depends on both the biocide dosed and on TOC, it is expected to decrease once the organic matter is eliminated.

Table 2. Trend of water parameters, after the implementation of the disinfecting system, in the first months of operation.

\begin{tabular}{lccccc}
\hline Water Sample & TOC (mg/L) & $\begin{array}{c}\text { Residual Free } \\
\text { Chlorine }(\mathbf{m g} / \mathbf{L})\end{array}$ & CFU/mL & $\begin{array}{c}\text { Total THMs } \\
(\boldsymbol{\mu g} / \mathbf{L})\end{array}$ & $\begin{array}{c}\text { Chloroform } \\
(\boldsymbol{\mu g} / \mathbf{L})\end{array}$ \\
\hline Before & $1.0 \pm 0.3$ & N.A. & $200 \pm 30$ & 0.5 & $<0.1$ \\
After 2 months & $1.1 \pm 0.2$ & $0.3 \pm 0.1$ & $6 \pm 5$ & 3.4 & $<0.1$ \\
After 4 months & $2.9 \pm 0.6$ & $0.2 \pm 0.1$ & $12 \pm 7$ & 4.6 & $<0.1$ \\
After 6 months & $1.7 \pm 0.3$ & $0.3 \pm 0.1$ & $2 \pm 1$ & 4.1 & $<0.1$ \\
\hline * The dosing of the biocide (up to 1.2 ppm at the point of injection) was adjusted to obtain the residual \\
concentration reported.
\end{tabular}

The technology is currently applied in many different healthcare facilities, in Italy, Spain, Germany and Slovenia. Test results required by the Australian Water Quality Centre (NATA approved laboratory) confirmed the effectiveness of anolyte against targeted organisms (Legionella pneumophila, Pseudomonas aeruginosa and Escherichia coli); as a result, negotiations are presently in progress with a healthcare facility in Australia to install the first machine.

Since also microorganisms belong to the class of "organic substrates", the anolyte-based approach may be considered as a form of indirect oxidation of organic substances [31,32]. The alternative direct oxidation [33-36] undoubtedly represents an interesting approach, maybe also more efficient (the inactivation of microorganisms does not rely only upon the synthesis of a biocide, being also consequence of electric field effects [37] and sudden variations of $\mathrm{pH}$ ) but the size of the reactor required to treat the entire water flow makes this method often impracticable.

\section{Conclusions}

The two case studies have shown that implementation of an in situ electrochemical technology for synthesis and dosing of hypochlorous acid eradicated Legionella contamination from two large hospital water systems.

Although the considered healthcare facilities did not provide us with all available data, the evidences are unquestionably in favor of the effectiveness of the proposed anolyte-based approach. In the two considered case studies, the Legionella colony counts decreased significantly within a few weeks from the beginning of the disinfection treatment. The total organic carbon content of the treated water showed 
to increase, as plausible consequence of the destruction of biofilm. As a temporary effect, also the level of THMs increased, anyway remaining well below the legislated limit (e.g., $30 \mu \mathrm{g} / \mathrm{L}$ in Italy). The technology demonstrates great potential for applicability in a variety of settings, with no negative consequences to infrastructure or potable water aesthetics. More information on implementation and performance of this system is clearly warranted.

\section{Acknowledgments}

The authors are indebted with Guglielmo Paganetto (Dept. of Life Sciences and Biotechnology, University of Ferrara, Italy) and with Claressa Lucas (Centers for Disease Control and Prevention, Atlanta, Georgia) for their helpful suggestions during the preparation of the manuscript.

\section{Author Contributions}

Study conception, design and data collection: F. Migliarina; Data analysis and interpretation: F. Migliarina and S. Ferro; Writing and revisions of the paper: S. Ferro.

\section{Conflicts of Interest}

The authors declare no conflict of interest.

\section{References}

1. Frank, S.A. Immunology and Evolution of Infectious Disease; Princeton University Press: Princeton (NJ, USA) and Oxford (UK), 2002; pp. 13-15.

2. Klebanoff, S.J. Myeloperoxidase: Friend and foe. J. Leukocyte Biol. 2005, 77, 598-625.

3. Hoffstein, S.T.; Gennaro, D.E.; Manzi, R.M. Neutrophils may directly synthesize both $\mathrm{H}_{2} \mathrm{O}_{2}$ and $\mathrm{O}_{2}{ }^{-}$ since surface stimuli induce their release in stimulus-specific ratios. Inflammation 1985, 9, 425-437.

4. Wang, L.; Bassiri, M.; Najafi, R.; Najafi, K.; Yang, J.; Khosrovi, B.; Hwong, W.; Barati, E.; Belisle, B.; Celeri, C.; et al. Hypochlorous acid as a potential wound care agent. Part I. Stabilized hypochlorous acid: A component of the inorganic armamentarium of innate immunity. J. Burns Wounds 2007, 6, 65-79.

5. Hampton, M.B.; Kettle, A.J.; Winterbourn, C.C. Inside the neutrophil phagosome: Oxidants, myeloperoxidase, and bacterial killing. Blood 1998, 92, 3007-3017.

6. Klebanoff, S.J. Mieloperoxidase. Proc. Assoc. Am. Physicians 1999, 111, 383-389.

7. Winterbourn, C.C. Biological reactivity and biomarkers of the neutrophil oxidant, hypochlorous acid. Toxicology 2002, 181-182, 223-227.

8. Len, S.V.; Hung, Y.C.; Erickson, M.; Kim, C. Ultraviolet spectrophotometric characterization and bactericidal properties of electrolyzed oxidizing water as influenced by amperage and pH. J. Food Prot. 2000, 63, 1534-1537.

9. Abadias, M.; Usall, J.; Oliveira, M.; Alegre, I.; Viñas, I. Efficacy of neutral electrolyzed water (NEW) for reducing microbial contamination on minimally processed vegetables. Int. J. Food Microbiol. 2008, 123, 151-158. 
10. Xiong, K.; Liu, H.-J.; Liu, R.; Li, L.-T. Differences in fungicidal efficiency against Aspergillus flavus for neutralized and acidic electrolyzed oxidizing waters. Int. J. Food Microbiol. 2010, 137, $67-75$.

11. Neodo, S.; Rosestolato, D.; Ferro, S.; de Battisti, A. On the electrolysis of dilute chloride solutions: Influence of the electrode material on Faradaic efficiency for active chlorine, chlorate and perchlorate. Electrochim. Acta 2012, 80, 282-291.

12. Bohnstedt, R.; Surbeck, U.; Bartsch, R. Membrane electrolytic reactors system with four chambers. European Patent n. 1969159 B1, 13 May 2009.

13. Regolamento concernente i materiali e gli oggetti che possono essere utilizzati negli impianti fissi di captazione, trattamento, adduzione e distribuzione delle acque destinate al consumo umano. D. Min. 174, 17.07.2004, G.U. n. 166 (In Italian).

14. Bakhir, V.M. Regulating physical and chemical properties of technological aqueous solutions by unipolar electrochemical exposure and experience of its practical application. Ph.D. Thesis, Kazan Institute of Chemical Technologies, Kazan, Tatarstan (Russia), 1985.

15. Prilutsky, V.I.; Bakhir, V.M. Electrochemically Actuating Water: Anomalous Characteristics, Mechanism of Biological Action; Nauka: Moscow, Russia, 1997; p. 232.

16. Faust, S.D.; Aly, O.M. Chemistry of Water Treatment, 2nd ed.; Lewis Publishers: New York, NY, USA, 1998; pp. 509-517.

17. Tamburini, E.; Bernardi, T.; Castaldelli, G.; Tumiatti, G.; Ferro, S. Green electrochemical approach for delignification of wheat straw in second-generation bioethanol production. Energy Environ. Sci. 2011, 4, 551-557.

18. Quadrelli, S.; Ferro, S. Electrochemical Reactor. Intern. Pat. Appl. n. WO 2010/055108 A1, 2010.

19. Lee, J.S.; Quan, N.D.; Hwang, J.M.; Lee, S.D.; Kim, H.; Lee, H.; Kim, H.S. Polymer electrolyte membranes for fuel cells. J. Ind. Eng. Chem. 2006, 12, 175-183.

20. Thorn, R.M.S.; Lee, S.W.H.; Robinson, G.M.; Greenman, J.; Reynolds, D.M. Electrochemically activated solutions: Evidence for antimicrobial efficacy and applications in healthcare environments. Eur. J. Clin. Microbiol. Infect. Dis. 2012, 31, 641-653.

21. Liste der Aufbereitungsstoffe und Desinfektionsverfahren, Trinkwasserverordnung 2008, gemäß 11-Teil I c. Available online: http://www.lra-mue.de/shared/data/pdf/liste_paragraf_11_stand_ juni_2008.pdf (accessed on 17 December 2014) (In German).

22. Italian guidelines for prevention and control of Legionellosis. 05.05.2000, G.U. n. 103.

23. International Organization for Standardization (ISO). Water Quality: Detection and Enumeration of Legionella; ISO 11731-2: 2008, Switzerland.

24. Descours, G.; Cassier, P.; Forey, F.; Ginevra, C.; Etienne, J.; Lina, G.; Jarraud S. Evaluation of BMPA, MWY, GVPC and BCYE media for the isolation of Legionella species from respiratory samples. J. Microbiol. Methods 2014, 98, 119-121.

25. International Organization for Standardization (ISO). Colorimetric method using N,N-diethyl-1, 4-phenylenediamine, for routine control purposes. In Water Quality: Determination of Free Chlorine and Total Chlorine; ISO 7393-2: 2002, Switzerland.

26. Verfahren zur Desinfektion von Trinkwasser mit Chlor und Hypochloriten, Arbeitsblatt W 229. 2008; DVGW technical rule. Available online: http:/www.beuth.de/de/technische-regel/dvgw-w229/110879513 (accessed on 17 December 2014) (In German). 
27. Attuazione della direttiva 98/83/CE relativa alla qualità delle acque destinate al consumo umano. D. Lgs. n. 31, 03.03.2001, G.U. n. 52.

28. Migliarina, F. Administrative services business, ASL AT, Asti, Italy, Personal Communication, 2014.

29. American Public Health Association (APHA); American Water Works Association (AWWA); Water Environment Federation (WEF). Standard Methods for the Examination of Water and Wastewater, 21st ed.; 2005. Available online: http://www.mwa.co.th/download/file_upload/SMW W_1000-3000.pdf (accessed on 17 December 2014).

30. APAT; IRSA-CNR. Metodi analitici per le Acque; Manuali e Linee Guida, APAT: Roma, 2003; p. 29.

31. Martinez-Huitle, C.A.; Ferro, S. Electrochemical oxidation of organic pollutants for the wastewater treatment: Direct and indirect processes. Chem. Soc. Rev. 2006, 35, 1324-1340.

32. Ghernaout, D.; Naceur, M.W.; Aouabed, A. On the dependence of chlorine by-products generated species formation of the electrode material and applied charge during electrochemical water treatment. Desalination 2011, 270, 9-22.

33. Bonfatti, F.; Ferro, S.; Lavezzo, F.; Malacarne, M.; Lodi, G.; de Battisti, A. Electrochemical incineration of glucose as a model organic substrate. Part 1: Role of the electrode material. J. Electrochem. Soc. 1999, 146, 2175-2179.

34. Martinez-Huitle, C.A.; de Battisti, A.; Ferro, S.; Reyna, S.; Cerro-Lopez, M.; Quiroz, M.A. Removal of the pesticide Methamidophos from aqueous solutions by electrooxidation using $\mathrm{Pb} / \mathrm{PbO}_{2}, \mathrm{Ti} / \mathrm{SnO}_{2}$ and $\mathrm{Si} / \mathrm{BDD}$ electrodes. Environ. Sci. Technol. 2008, 42, 6929-6935.

35. Ferro, S.; Martinez-Huitle, C.A.; de Battisti, A. Electroxidation of oxalic acid at different electrode materials. J. Appl. Electrochem. 2010, 40, 1779-1787.

36. Furuta, T.; Tanaka, H.; Nishiki, Y.; Pupunat, L.; Haenni, W.; Rychen, P. Legionella inactivation with diamond electrodes. Diamond Relat. Mater. 2004, 13, 2016-2019.

37. Chen, D.-Q.; Huang, S.-S.; Lu, Y.-J. Efficient transformation of Legionella pneumophila by high-voltage electroporation. Microbiol. Res. 2006, 161, 246-251.

(C) 2014 by the authors; licensee MDPI, Basel, Switzerland. This article is an open access article distributed under the terms and conditions of the Creative Commons Attribution license (http://creativecommons.org/licenses/by/4.0/). 